\title{
Erratum to: Purification and biochemical characterization of recombinant alcohol dehydrogenase from the psychrophilic bacterium Pseudomonas frederiksbergensis
}

\author{
Rudolph Fredua-Agyeman • Ahmed Abdel-Megeed • \\ Rudolf Mueller
}

Published online: 10 May 2011

(C) Springer Science+Business Media, LLC 2011

\section{Erratum to: J Polym Environ (2010) 18:617-625 DOI 10.1007s10924-010-0205-0}

The authorship of this article is changed to Rudolph Fredua-Agyeman, Ahmed Abdel-Megeed, and Rudolf Mueller. The remaining two authors Mourad A. M. AboulSoud and Salem S. Al-Deyab are acknowledged in the Acknowledgment section.

In the original publication, the author's name FreduaAgyeman Rudolph was misspelled and is corrected here. below:

Also, the new affiliations for the author's are given

Rudolph Fredua-Agyeman

University of Alberta,

Department of Agricultural, Food and Nutritional Science, Canola Breeding Group,

432D Agric/Proteomics and Genomics Lab,

Edmonton, AB T6G 2P5, Canada.

The online version of the original article can be found under doi: 10.1007/s10924-010-0205-0.

R. Fredua-Agyeman

Department of Agricultural, Food and Nutritional Science,

Canola Breeding Group, University of Alberta, 432D Agric/

Proteomics and Genomics Lab, Edmonton AB T6G 2P5, Canada

A. Abdel-Megeed

Botany and Microbiology Department, King Saud University,

P.O. Box 2455, Riyadh 11451, Kingdom of Saudi Arabia

R. Mueller $(\square)$

Technical University Hamburg-Harburg (TUHH),

Biotechnology II, Room 1511, Denickestrasse 15 (K),

21073 Hamburg, Germany

e-mail: ru.mueller@tu-harburg.de
Ahmed Abdel-Megeed

Botany and Microbiology Department,

King Saud University,

P.O. Box 2455, Riyadh 11451,

Kingdom of Saudi Arabia.

Rudolf Mueller

Technical University Hamburg-Harburg (TUHH),

Biotechnology II, Room 1511, Denickestrasse 15 (K),

21073 Hamburg, Germany.

Corresponding author email: ru.mueller@tu-harburg.de

Acknowledgments:

We would like to thank Dr. Mourad A. M. Aboul-Soud (Abdul Rahman Al-Jeraisy Chair for DNA Research) and Dr. Salem S. Al-Deyab (Petrochemical Research Chair, Department of Chemistry) of the King Saud University Kingdom of Saudi Arabia for reading and revising the manuscript. 